\title{
Bank Vole Populations: Are their Densities Really High and Individual Home Range Small?
}

\author{
Roman ANDRZEJEWSKI \& Joanna BABINSKA-WERKA
}

\begin{abstract}
Andrzejewski R. \& Babińska-Werka J., 1986: Bank vole populations: are their densities really high and individual home range small? Acta theriol., 31, 30: 409-422 [With 1 Table \& 6 Figs.]

The sizes of home ranges and population density in Clethrionomys glareolus (Schreber, 1780) have been determined in a 5-day period by use of a trap line consisting of 80 sites ( 2 traps per site) spaced every 15 metres. Three days prior to, and during the trapping period oat grain was offered in sets of 4 plastic boxes set in corners of $4 \times 4 \mathrm{~m}$ squares between stands 20 and 21 , and 60 and 61 . 68 bank voles were caught. Oats were found in the stomachs of 56 voles caught at sites located at all possible distances from exposition sites. The percentage of oats in the stomachs was negatively correlated with the distance between the point of catching and the oat exposition site. The individuals that had no oat in stomachs were all caught at stands more than $200 \mathrm{~m}$ from the exposition sites. Similar relationships were established for reproducing females. It was assumed that: (1) the $300 \mathrm{~m}$ range of penetration around oat supply sites is either a long axis of an elliptic range or a radius of a circular one, (2) the fact that around 30 individuals could visit each exposition site meant that at least 30 home ranges overlapped there. With these assumptions applied, the estimated area of a home range was 3.5 (elliptic), or 7.0 hectares (circular), and corresponding population densities were 4.25 to 8.50 individual per hectare. The size of zone affected by the trap line has been estimated to cover 72 hectares and the effectiveness of removal at any trap site to be at 12 to 24 per cent. The need to review all the population parameters determined on plots of a several hectare size "saturated" with traps is therefore stressed.

[Department of Game Management, Agricultural University of Warsaw, Rakowiecka 26/30, 02-528 Warszawa, Poland]
\end{abstract}

\section{INTRODUCTION}

The theory of population ecology of small mammals has been built mainly on the basis of information gathered on sample plots with dense networks of live traps. Various modifications of the CMR method have been applied in field studies carried out on such plots. Much less often snap traps have been used e.g. in a standard method of the International Biological Programme (Grodziński et al., 1966). Time required for operating such methods has prevented both increasing numbers of 
plots and studying the population parameters on larger areas (Chelkowska \& Goszczyński, 1983).

It has been therefore too easily assumed that the results obtained on plots of 1 to 6 hectare size represented the entire population of an ecosystem.

Ecology has been now increasingly involved in studying problems fertaining to large areas. A persisting question arises: will the parameters estimated on small sample plots hold for larger areas (say: of a size comparable to the whole ecosystem), even relatively homogenous with respect to living conditions for rodents.

The aim of this study was to work out the method of estimating the population parameters in Clethrionomys glareolus (Schreber, 1780) on an area markedly exceeding the several-hectare plots used routinely in such studies.

\section{METHOD}

The study was carried out in northeastern Poland in the vicinity of Suwałki Landscape Reserve (Turtul Research Station) in July 1985. The site consisted of 200 hectares of a 50-year old pine forest stand planted here on previously arable land. The area was relatively homogenous in respect to environmental conditions. In rodent fauna, $C$. glareolus dominated and there were also few Apodemus flavicollis (Melchior, 1834) and Microtus agrestis (Linnaeus, 1761) present.

In the forest a 1200 metres long trap line was set up with 80 numbered sites arranged in 15 metres distances from each other. There were two snap traps in each stand inspected every $24 \mathrm{hrs}$ over a five day period to remove catches. A plastic sponge soaked in vegetable oil was used as a bait.

Between stands No 20 and 21, and 60 and 61, groups of four plastic boxes with oat grain were placed, at about 4 meters distance from each other, close to the places likely to be visited by rodents such as tree barks, bushes and the like. The grain was offered for three days preceding the trapping session and during the period itself, with the grain replenished when needed.

The reproductive status of the rodents caught was determined by dissection. The stomachs were removed and frozen: the oat starch was separated from the rest of stomach contents. Characteristic features of oat starch made this procedure quite easy. The fraction of oat starch was estimated with accuracy to within $5 \%$ (in fresh mass).

The exposition of oat grain was therefore used as a method for self-marking of rodents which visited 20 th and 60 th stands and ate the grain there. Hence the position of other stands have been differentiated 
in relation to their distance from the sites where the grain was offered. As a result, four identical gradient zones were formed with respect to distance from the sites with grain: from stand 20 to 1 , from 21 to 40 , from 60 to 41 , and from 61 to 80 . Each gradient zone included 20 stands and was 300 metres long.

\section{RESULTS}

\subsection{Number of Bank Voles in the Zone Affected by Trap Line}

The number of voles that lived in the zone affected by the trap line (henceforth called affected zone) has been estimated by means of simple regression (De Lury, 1947; Hayne, 1949). In all, 68 individuals were

Table 1

Actual numbers of animals caught and regression-derived estimates.

\begin{tabular}{lccc}
\hline & Males & Females & Total \\
\hline $\begin{array}{l}\text { Number of animals } \\
\text { caught }\end{array}$ & 29 & 39 & 68 \\
$\begin{array}{l}\text { Regression equation } \\
\begin{array}{l}\text { Correlation coefficient } \\
\text { equation r }\end{array}\end{array} y=10.82-0.31 x$ & $y=17.96-0.43 x$ & $y=28.54-0.38 x$ \\
$\begin{array}{l}\text { Estimated number } \\
\text { of voles }\end{array}$ & -0.9420 & -0.9996 & -0.9950 \\
\hline
\end{tabular}

caught including 29 males and 39 females. The estimates yielded by the regression method amounted to $75.3 \pm 2.8$ individuals including $34.5 \pm 3.8$ males and $41.8 \pm 1.0$ females (Table 1 ). The removal was intensive as is implied by the high proportion of animals caught $-90.7 \%$ of the estimated total number of individuals.

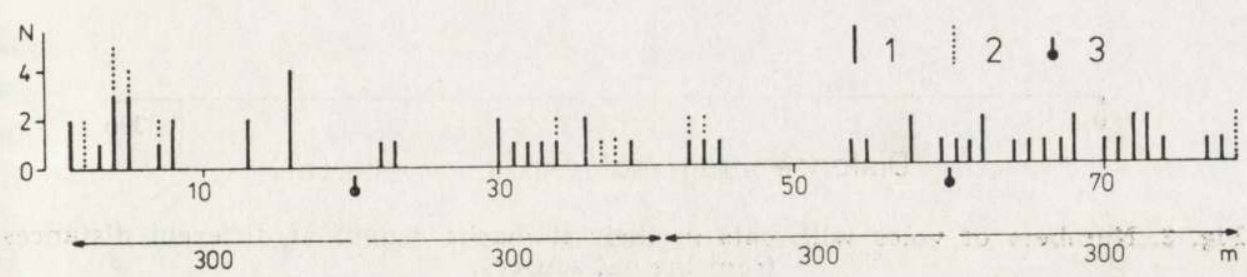

Fig. 1. The numbers of voles caught at various trap sites. 1 - voles witn oat in stomachs, 2 - voles without oat in stomachs, 3 - sites of oat provisioning.

The estimated number of animals calculated per 100 trap/days is 18.75. This figure approaches the numbers reported by Bashenina (1981) for high densities, although in a standard method used in the USSR 
the traps are arranged at small distances (every $5 \mathrm{~m}$ ) and in short lines (20-25 traps).

The number of voles caught at particular stands did not deviate from Poisson's distribution. The distribution of catches along the trap line showed several empty spaces spanning over several adjacent trapsites (Fig. 1).

\subsection{Voles Caught with Oats in Stomachs}

56 individuals ( $92 \%$ of total number) were caught with oats in stomachs i.e. they must have visited the sites where oat grain was deposited. The regression line $(y=23.16-0.38 x, r=0.9876$ significant at $0.01<p<0.001$ ) estimated the number of such animals present in the affected zone by the trap line at $61 \pm 3.8$ individuals $(81 \%$ of total estimated number of 75 individuals). At the same time, 13 individuals without oat in stomachs were caught. Similar procedure (regression equation $y=5.57-0.40 x, r=-0.8934,0.05<p<0.02$ ) yielded the estimate of $15.0 \pm 2.8$ of such individuals in the affected zone.

The following analysis of the distribution of voles caught along the trap line with or without oats in stomachs have been attempted. Sums of the numbers of the voles caught at the same distance from the provisioning sites were made separately for animals with, and without oats in stomachs. Thus, for each given distance, the number of catches was represented by four replicates.

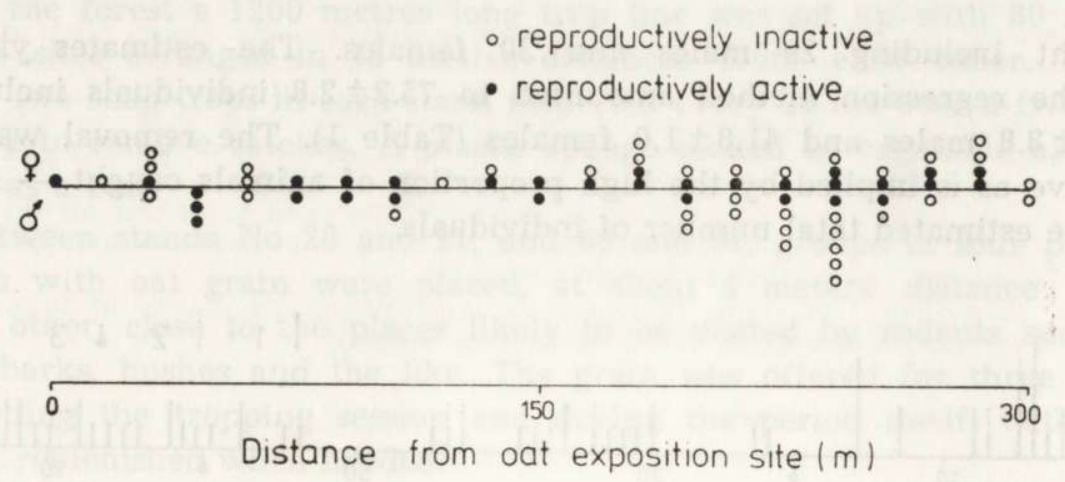

Fig. 2. Numbers of voles with oats in their stomachs caught at different distances from the oat sources.

It was found that the voles with oats in stomachs were caught within the whole $300 \mathrm{~m}$ distance on each side of the exposition site i.e. along the whole trap line. All the voles caught within $200 \mathrm{~m}$ distance had oats in stomachs. The voles without oats in stomachs were all caught at distances exceeding $200 \mathrm{~m}$ (Fig. 1). 
Since it is accepted in literature that sexually active females occupy smaller, non overlapping areas because of their territorial behaviour (Mazurkiewicz, 1985 and others) the distribution of female catches along the length of the trap line has also been considered. Again it was found that the females taking part in reproduction (20 in all) that visited the oat exposition sites were caught at various distances from these sites, up to $285 \mathrm{~m}$ (Fig. 2).

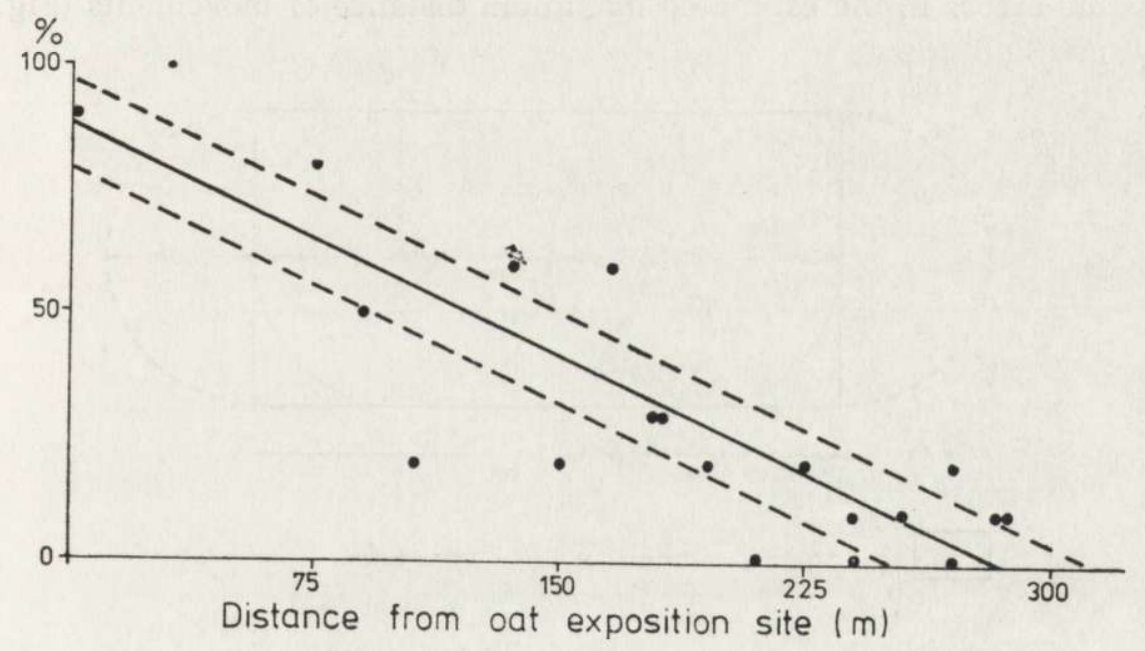

Fig. 3. Fraction of oats found in stomachs of reproducing females at various distances from the oat sources.

The changes in the oat fraction in stomachs of voles caught at various distances from the exposition sites have also been studied. The correlation between the oat fraction size and the distance was linear, high, and negative $(r=-0.8652$ at $p<0.001)$. Thus the longer the distance the lower fraction of oats was found in the stomachs. The regression line for the percentage of oat in stomach contents allowed estimation of a distance at which there should be no oats in stomachs $(y=0, x=$ $=285 \pm 31$ ). This value indicates how low was the possibility that an animal visiting the oat baits would be caught at a distance of more than $300 \mathrm{~m}$, i.e. in the zone influenced by an adjacent oat source.

The fractions of oats in the stomachs of females followed a similar pattern $(y=88.08-0.31 x, r=-0.8652, p<0.001$, when $y=0, x=284 \pm 32)$ (Fig. 3). 


\subsection{Estimation of the Area Affected by the Trap Line}

The fact that the voles which visited the sites with oat grain (being actually, the sites of self-marking) were caught within the distance of less than $300 \mathrm{~m}$ allowed assuming that the zones of penetration by these individuals formed circles around these sites with $300 \mathrm{~m}$ radius. Each part of the trap line with 40 traps constituted the radius of such a circle. In the experiments described here these circles were tangential to each other on the trap line (with reservations resulting from the rossible errors in the estimated maximum distance of movements (Fig. 4).

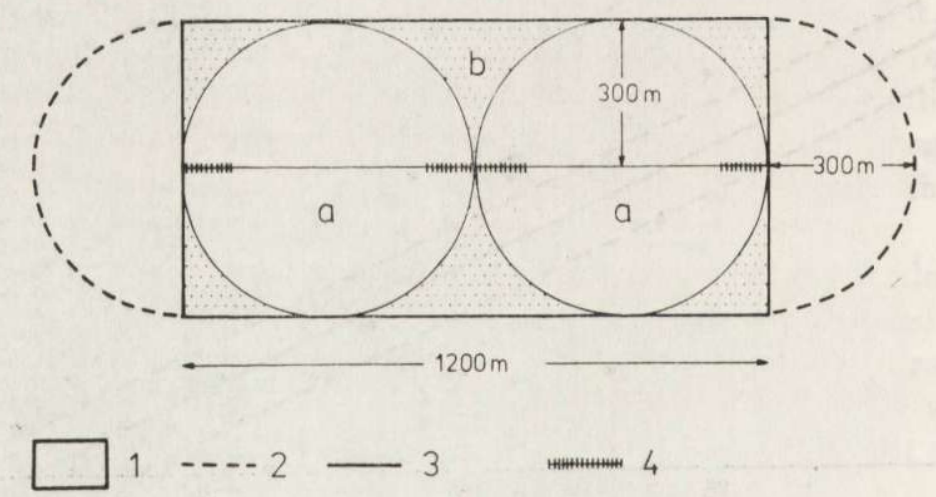

Fig. 4. The zone affected by the trap line, 1 - the main zone, 2 - accessory zone, 3 - trap line, 4 - part of the trap line which caught animals without oat in stomachs, a - the area from which the voles could reach the oat exposition sites, $\mathrm{b}-$ the area from which the voles could not reach the oat bait sites.

If such zones exist around the two bait sites on the trap line, it can therefore be assumed that the whole trap line will affect the area of a rectangle that is $1200 \mathrm{~m}$ long and $600 \mathrm{~m}$ wide, and has area of $720,000 \mathrm{~m}^{2}$ (Fig. 4).

The two ends of the trap line might have also been visited by the animals from semi-circular adjacent zones of the same $300 \mathrm{~m}$ radius. The chance, however, was relatively low as the last stand in the line merely bordered the affected zone while the rest of the trap line cut through the whole of the main zone. The animals living in the adjacent zone whose home ranges overlapped more then one trap would certainly have higher chance of being caught.

The problem of removal of the animals from the adjacent zones is difficult to solve. The zone covered (at both ends of the trap line) the area of $280,600 \mathrm{~m}^{2}$ that made $39 \%$ of the main zone. However, the 
surplus of catches in this accessory zone was not signifficant; hence in further calculations of population parameters the accessory zones have not ween taken into account.

The main zone affected by the trap line consists of two areas: a) the one in which the animals had the chance of visiting the site of oat exposition, and b) the area where the animals had no such chance because distances exceeded $300 \mathrm{~m}$ from the oat bait sites. The above hypothesis is supported by the distribution of catches with no oats in stomachs. These animals were caught exclusively within the parts of the trap line that were located closer to the areas from where the animals had no chance of self-marrking with oats (Fig. 4).

The areas frequented by the animals that could not self-mark covered $22 \%$ of the main zone affected by the trap line. The fraction of the animals caught with no oat in stomach was $20 \%$ of the total. Perhaps, this coincidence is not an accidental one.

\subsection{Estimation of Population Density}

It is widely accepted that the bank vole populations consist of migrating individuals as well as those permanently inhabiting given area. The high number of individuals that were caught after visiting the oat exposition site and the high rate of their removal allow assumption that they have belonged mainly to the permanent inhabitants of the area. Such voles have home ranges of 1,000 to $7,000 \mathrm{~m}^{2}$ (Bashenina, 1981; Mazurkiewicz, 1983, cf. also the literature cited there). A generalized shape of such home ranges according to the recently suggested model resembles an ellipse with axis ratio about 2 to 1 (Mazurkiewicz, 1969, 1983 and others).

The ranges penetrated by voles in the experiment described in this study exceed the above figures many times. A hypothesis stating that voles may have some sort of communication system to pass on information about attractive feeding sites thus inducing some to leave home ranges to visit a new "grocery" may be discarded a priori as too anthropomorphic. It was therefore assumed that the voles occupy areas in which the distance of their linear movements does not exceed $300 \mathrm{~m}$.

The hypothesis of an elliptic shape of home ranges in the bank vole put forward by Mazurkiewicz (1969) can be accepted, as one of the possible models, on the basis of the spatial activity of voles determined in this study. Nevertheless, an older model of circular ranges proposed by Calhoun and Casby (1958) presents, in case of high activity of individuals, some heuristic attractiveness.

When the long axis of the elliptic range was assumed to be equal to the maximum distance covered, i.e. $300 \mathrm{~m}$, the area of the range amounted 
to $35,325 \mathrm{~m}^{2}$. The same $300 \mathrm{~m}$ distance applied as the radius of a circular range yielded an area estimated at $70,659 \mathrm{~m}^{2}$.

On the basis of these values the density of voles in the area affected by the trap line was estimated. Because of such large home range areas some problems with estimating the border zone of the main area can be expected. Hence the following line of reasoning was applied:

The two sites with oats were visited by an estimated number (by regression method) of $61 \pm 3.8$ individuals i.e. by about 30 individuals each. This means that at these sites 30 home ranges have overlapped. In fact, the site between the 20th and 21st stands may be allocated to 28 individuals, and the site between 60 th and 61 st stands to 27 individuals (Fig. 1).

If it is assumed that the frequency of penetration of the home range is high enough - the probability of finding a given individual on $1 \mathrm{~m}^{2}$ of elliptic range is $1 / 35,325$, and $1 / 70,650$ in case of a circular range. If there are 30 overlapping ranges at any place chance of finding there on $1 \mathrm{~m}^{2}$ any of the individuals is $30 / 35,325$ or $30 / 70,650$. The corresponding densities in the area amount to 8.5 individual per hectare when the elliptic shape of ranges is applied, and 4.25 individual per hectare in case of circular ranges. The estimation of numbers of voles living in the zone affected yielded figures of 612 and 306 individuals, respectively. The above estimates do not depend on effects occurring on edges when the removal is carried out on plots. In contrast, the number estimates are very dependent on estimates of home range size. The density estimates obtained in this study have approached lower values among those known from literature (Bashenina, 1981).

The dynamic characteristics of the space utilization by voles implies that linking the individuals with certain sites is no longer feasible. The idea might be replaced by the area penetrated by voles and there the density (overlapping) of the ranges should be analyzed (Andrzejewski \& Symonides 1982). The above density estimates should be treated rather as a probable number of vole nests (because of their permanent nature in the area) that could exist within the zone affected by a trap line (if an individual occupies only one and only its own nest).

\subsection{Effectiveness of Removal by the Trap Line}

The number of rodents that were removed by traps calculated as a fraction of the total number estimated for the zone affected reached 12.25 or $24.50 \%$ respectively for the elliptic and circular home ranges. A question arises why only such small numbers have been caught. 
The following line of reasoning has therefore been applied. One can imagine that home ranges of voles are arranged in some 30 "layers" over the entire area; where one range ended, another range began fairly close. If the elliptic shape of ranges was assumed the trap line cut the ranges at many angles and divided them into various parts. In the extreme case the situation allowing the trap line to catch "the owner" of the range occurred when the long axis of the range met the trap line at the right angle, and the range itself was positioned tangentially to the line so that at least one trap was set in the range penetrated by "the owner" of the area. Such situation determined effective zone affected by the trap line. Usually however, the trap line cut the ranges that did not reach the borders of affected zone i.e. the ranges that were completely covered by the effect of the trap line. By this, beyond these borders there were ranges that might completely or partially lie within the affected zone but, having no contact with the traps themselves made catching their "owners" impossible (Fig. 5).

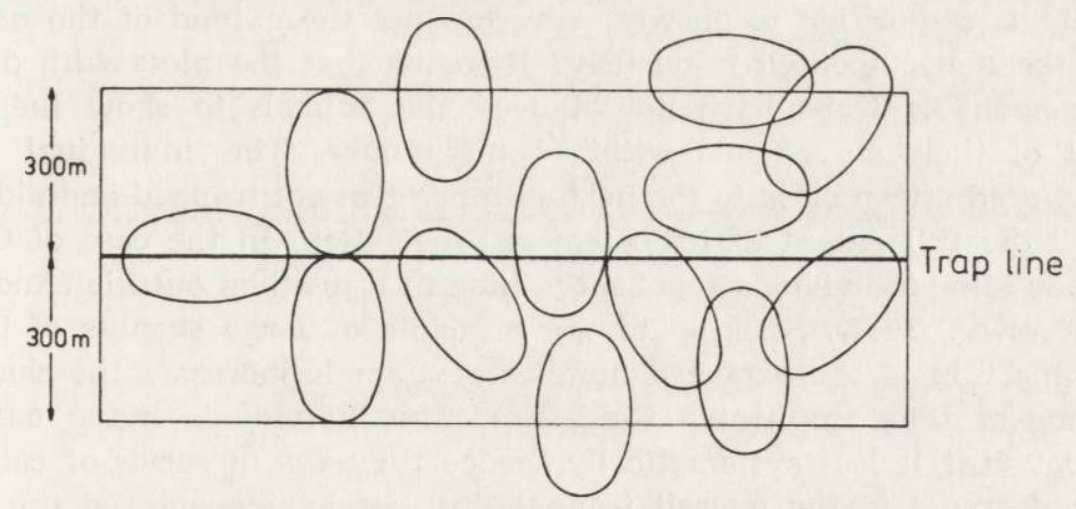

Fig. 5. Various possible positions of home ranges of voles in the zone affected by the trap line.

In case of circular range model the diameter of the range determined the extend of affected zone and more ranges were cut by the trap line (because of their greater size). Here again numerous ranges within the zone affected had no contract with the trap line.

The above reasoning helps to explain the problem why only a part of the population living in the zone affected by trap line has been removed. It may therefore be expected that after the removal effected by the initial trap line some more animals may still be recovered from 
combination of two trap lines would certainly be an interesting testing procedure for the method proposed in this study but in time of the experiments the authors had not have enough knowledge to apply it.

\section{DISCUSSION}

The distance of $300 \mathrm{~m}$ penetration range is nothing new to the specialists studying the bank vole. Such distant catches have been reported and explained as "exploratory" ventures out of home ranges (Ilenko \& Zubčaninova 1963).

It has been, however, commonly accepted that the number of overlapping ranges in voles is small (less than 10), and that the females actively participating in reproduction may even tend towards territorialism and may be avoiding contacts with other females (Bujalska, 1970 and others). The results of the present experiment seem to challenge those notions.

There is a question to answer; why has not the extend of the movements been documented previously? It seems that the plots with dense arrangement of traps have not allowed the animals to show the full extent of their movements within home ranges. The individual that encountered a trap close to the nest entrance just got trapped and did not "show" the full extent of its potential penetration. In the case of CMR methods some individuals spent more time in traps then outside (Andrzejewski et al., 1967). Sticking to the principle of large surplus of traps in comparison to the expected number of animals increases the chances of removal thus amplifying the effect. The individuals living outside the plot visit it less systematically, hence the gaps in series of catches and a decrease in the overall trappability; yet having entered the plot they are caught at once thus being prevented from further movement about the plot. The experimental plot with a dense network of traps inhibits the movements of animals and distorts the picture of these movements. This ecological phenomenon has been previously discussed (Andrzejewski \& Dominas, 1963). The methodological approach presented in this paper is by no means immune to the inhibitory effect on animal movements but its extent is markedly limited.

Any attempt to explain the interesting observation of a decrease in oat fraction in stomachs with increasing distance between the site of self-marking and the site of trapping calls for much wider knowledge of spacing behaviour in voles and, generally, of oat digestibility than is available now.

This study offers a model of the effectiveness of a trap line in applica- 
tion to population censuses. The authors are fully aware of how many and controversial assumptions have been made in this model.

The results lead to the necessity of changing our ideas about the dynamics of the space behaviour in bank voles. They may also shake the traditional picture of the shape of home ranges although the universality of home range definition will allow it to remain in use although with some parameters of its characteristics changed. It has been assumed (after Wierzbowska, 1971) that the probability of catching an animal is equal at any point in its home range. However, this goes against the models proposed by Calhoun and Casby (1958) and Mazurkiewicz (1969) that indicate more frequent activity around a centre of activity. The whole concept of the centre of activity and the concentration

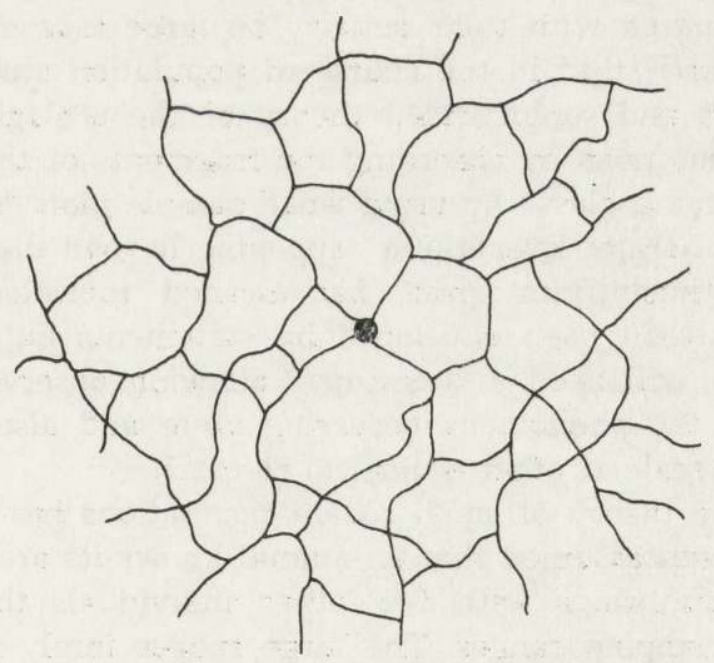

Fig. 6. A hypothetical system of paths used by a vole, - burrow.

of catches around it may also be discussed against the background of observations indicating that the bank voles (and indeed other rodent species) move about their range on a network of pathways leaving the spaces among them unpenetrated (Petrov \& Mironov, 1972 and others). When the distance covered daily by the animal is large, the frequency of its visits to the different parts of range will depend mainly upon the uniformity of the coverage of range by these pathways and not on the distance between a site and the nest (Fig. 6).

The estimation of population density as given above does not include provision for unequal distribution of ranges in space, and does not give 
estimates of statistical errors for the numbers of overlapping ranges, and the population densities. Thus the study bears a stigma of a tentative publication that is intended to incite more field work and discussion. In light of the data gathered so far, the likely points for the discussion seems to cover the following points: 1) the spatial organisation of population and the estimates of intrapopulation migration, (2) the social population structure under the conditions of the high spatial activity, multiple overlapping of home ranges, and low population densities, (3) the reliability of the estimates of population density made on small plots (of several hectare size) by CMR or complete reinoval methods (hectare size), (4) the estimates of productivity of populations and their impact on the food resources based on the above data, (5) the estimates of the energy requirements of rodents obtained in the metabolic cages allowing only restricted activity on part of the animals as compared with their activity on large ranges etc.

It may be feared that in the course of population studies, we developed a coherent and sophisticated theory of the ecological phenomena going on in populations by observing the fragments of these populations under a "magnifying glass" by using small sample plots "saturated" with large numbers of traps. Everything happening beyond the field of observation of this "magnifying glass" has escaped theriologists attention. The theory has soon been enveloped by statements build on artefacts. Future research will need a "telescope" allowing observations on large areas to reveal the phenomena occurring there and also to bring it in to ine with the scale of other ecological research.

Until now, the theory of small rodent populations has been relatively "hard". It has been assumed that an animal knows its area well, and has determined relationships with few other individuals that rule neighbouring or overlapping ranges. The large ranges imply much less control exercised by the individual over the environment and neighbours. The role of the common relationship the animals have with their cnvironment, as well as importance of much looser relationships with numerous inhabitants of a given space increases. The theory of small rodent population might thus become "softer", with even more poplilation touch in it.

\section{REFERENCES}

1. Andrzejewski R. \& Dominas H., 1963: Niektóre problemy intensyfikacji metodyki ekologicznej. Ekol. pol. B, 13: 291-298.

2. Andrzejewski R., Petrusewicz K., \& Waszkiewicz-Gliwicz J., 1967: The trappability of Clethrionomys glareolus (Schreber, 1780) and other ecological parameters obtained by the CMR method. Ekol. pol. A, 15: 705-725. 
3. Andrzejewski R., \& Symonides E., 1982: Organizacja przestrzenna populacji roślin i zwierząt. Wiad. ekol., 28: 87-124.

4. Bashenina N. V., (ed.) 1981: Evropejskaja ryžaja polevka. Izd. Nauka 1-351. Moskwa.

5. Bujalska G., 1970. Reproduction stabilizing elements in an island population of Clethrionomys glareolus (Schreber, 1780). Acta theriol., 15: 381-412.

6. Calhoun J. B., \& Casby J. V., 1958: Calculation of home range and density of small mammals. US Publ. Health Monogr., 55: 1-24, Washington.

7. Chełkowska H., \& Goszczyński J., 1983: Numbers - methods of assessment. [In Petrusewicz K., (ed.) "Ecology of the bank vole".] Acta theriol., 28, Supl. 1: $94-101$.

8. De Lury D. B., 1947: On the estimation of biological population. Biometrics, 3: $145-167$

9. Grodziński W., Pucek Z., \& Ryszkowski L., 1966. Estimation of rodent numbers by means of prebaiting and intensive removal Acta theriol., 11: 297-314.

10. Hayne D. W., 1949: Two methods for estimating population from trapping records. J. Mammal., 30: 399-411.

11. Ilenko A. J., \& Zubčaninova E. V., 1963: Kruglogodiěnye nabljudenija za meŁenymi ryžimi polevkami i lesnymi myšami v Podmoskove. Zool. Zurn., 42: $609-617$.

12. Mazurkiewicz M., 1969: Elliptical modification of home range pattern. Bull. Acad. Pol. Sci. Cl. II, Ser. Sci. biol., 17: 427-431.

13. Mazurkiewicz M., 1983. Spatial organization of the population. [In: Petrusewicz K., (ed.) "Ecology of the bank vole".] Acta theriol. 28, supl. 1: 117-127.

14. Petrov O. V., \& Mironov A. D., 1972: Peredviženije ryžej polevki v predelach individualnego učastka. Ekologia, 1: 101-103.

15. Petrusewicz K., (ed.) 1983: Ecology of bank vole. Acta theriol. 28, Supl. 1: $1-242$.

16. Ryszkowski L., 1971: Estimation of small rodents density with the aid of coloured bait. Ann. Zool. Fennici, 8: 14-16.

17. Wierzbowska T., 1971. Statistical estimation of home range size of small rodents. Ekol. pol. A, 20: 781-831.

Accepted, July 14, 1986.

\section{Roman ANDRZEJEWSKI i Joanna BABIŃSKA-WERKA}

POPULACJA NORNICY RUDEJ: CZY RZECZYWISCIE JEJ ZAGESZCZENIE JEST DUŻE A OSOBNICZE AREAŁY MAŁE?

\section{Streszczenie}

Oceniono wielkosć areałów osobniczych i zagęszczenie Clethrionomys glareolus (Schreber, 1970) ustawiając w 50-letnim lesie sosnowym linię 80 punktów połowu gryzoni rozmieszczonych w odległościach co $15 \mathrm{~m}$ (Ryc. 1). W każdym punkcie znajdowały się 2 pułapki zabijające, a odłów trwał 5 dób. Na 3 dni przed odło- 
wem i. w czasie odłowu między punktami nr 20 i 21 oraz 60 i 61 eksponowano ziarno owsa wystawione w 4 naczyniach plastikowych rozmieszczonych $w$ narożnikach kwadratu o boku $4 \mathrm{~m}$. Złowionym osobnikom sekcyjnie oznaczono kondycję rozrodczą i procentową zawartość skrobi owsa w treści żolądkowej.

Odłowiono 68 osobników przy regresji wyłowu w kolejnych dniach $y=28,54-$ $-0,38 x, r=-0,9950$, przy $y=0, x=75,3 \pm 2.8$ (Tabela 1 ). Owies znaleziono $w$ żołącikach-56 nornic odłowionych na wszystkich odległościach od miejsca ekspozycji owsa. (Ryc. 1). Procentowy udział owsa w żołądkach był ujemnie skorelowany $(r=-0,8494$, przy $p<0,001)$ z odległością złowienia się osobnika od punktu, w którym eksponowano owies, a prosta regresji owsa $y=82,56-0,29 x$ przy $y=0$ dała $x=285 \pm 31 \mathrm{~m}$. Te same prawidlowości dotyczyły samic biorących udzial $\mathrm{w}$ rozrodzie (Ryc. 3). Osobniki bez owsa w żołądkach złowiły się tylko powyżej $200 \mathrm{~m}$ od miejsc ekspozycji owsa.

Przyjęto, że zasięg penetracji osobników wokół owsa wynoszący około $300 \mathrm{~m}$ jest długą osią areału eliptycznego lub średnicą areału kolistego. Około 30 osobników odwiedziło każde miejsce ekspozycji owsa, co oznacza, że w tych punktach nakładało się po 30 areałów (Ryc. 4). Oceniono powierzchnię areału na 3,5 do 7,0 ha, zagęszczenie na 4,25 do 8,5 osobników na hektar, strefę oddziaływania linii pułapek na 72 hektary i nasilenia wyłowu osobników z tej strefy na 12 do $24 \%$.

W dyskusji poddaje się krytyce parametry populacji oszacowane na podstawie kilku hektarowych powierzchni próbnych gęsto obstawionych pułapkami, ponieważ metoda ta jest przyczyną artefaktów. 